Jurnal Ilmu-Ilmu Peternakan 26 (3): 38 - 41

ISSN : 0852-3681

E-ISSN : 2443-0765

CFakultas Peternakan UB, http://jiip.ub.ac.id/

\title{
Kualitas spermatozoa semen beku sapi Simental dengan suhu dan lama thawing yang berbeda
}

\author{
E. D. Kusumawati, A. T. N. Krisnaningsih, dan R. R. Romadlon \\ Fakultas Peternakan Universitas Kanjuruhan Malang \\ J1. S. Supriadi No 48 Malang \\ enike@unikama.ac.id
}

\begin{abstract}
This study aims to investigate the quality of Simental frozen semen based on the temperatures and duration of thawing. The materials used in this study were frozen semen of Simental cattle. The study used a laboratory experiment using a completely randomized design $(\mathrm{CRD})$ factorial with 6 treatments and 10 replications. The thawing temperatures were $37^{\circ} \mathrm{C}$ and $25^{\circ} \mathrm{C}$ and the durations of thawing were 7 seconds, 15 seconds and 30 seconds. The variables observed in this study were the motility, viability and abnormality of Simental frozen semen. The data were analyzed using analysis of variance (ANOVA). The difference in advanced test was done by using the smallest Real Difference Test. The results showed that the temperature and duration of thawing and the interaction of temperature and duration of thawing provide a highly significant difference $(\mathrm{P}<0.01)$ on motility, viability and abnormality of Simental frozen semen. The highest motility $(45,5 \%)$ and viability $(75,65 \%)$ were found on $37^{\circ} \mathrm{C}$ and during 30 seconds of thawing, and the lowest abnormality was $4,71 \%$. This study concludes that the optimal thawing temperature and the lenght of thawing for Simental frozen semen is $37^{\circ} \mathrm{C}$ and 30 seconds respectively.
\end{abstract}

Keywords:thawing, sperm, motility, viability, temperature, abnormality

\section{PENDAHULUAN}

Sapi Simental memiliki persentasi karkas tinggi dan dapat difungsikan sebagai sapi potong dan perah dengan pertambahan bobot badan berkisar 0,6 sampai 1,5 kg per hari (Yunus, 2014). Sapi ini memiliki ciri-ciri warna kuning sampai merah serta memiliki warna putih pada muka, rambut ekor dan dada serta tidak bertanduk.

Pemeriksaan atau evaluasi semen segar terbagi menjadi 2 kelompok, yaitu pemeriksaan secara makroskopik dan pemeriksaan mikroskopik. Pemeriksaan secara makroskopi meliputi warna semen, bau semen, volume se- men, konsistensi dan $\mathrm{pH}$ semen. Sedangkan pemeriksaan mikroskopik meliputi motilitas massa, motilitas individu, viabilitas spermatozoa, konsentrasi dan abnormalitas spermatozoa (Kartasudjana,2001; Yendraliza, 2008).

Pengenceran dan penyimpanan bertujuan untuk menurunkan aktifitas metabolisme yang berlebihan agar dapat memperpanjang waktu hidup spermatozoa didalamnya, bahan pengencer yang digunakan hendaknya mampu menyediakan zat-zat makanan sebagai sumber energi, mencegah stress dingin, mencegah pertumbuhan mikroorganisme dan sebagai buffer (Hafez, 2008). 
Thawing merupakan proses pencairan kembali semen beku ketika akan dipergunakan. Thawing sangat bergantung pada suhu dan lama waktu thawing. Penelitian ini bertujuan untuk mengevaluasi kualitas spermatozoa semen beku sapi Simental dengan suhu dan lama thawing yang berbeda.

\section{MATERI DAN METODE}

Penelitian dilaksanakan di Laboratorium Terpadu Fakultas Peternakan Universitas Kanjuruhan Malang pada tanggal 01 - 30 November 2016. Straw sapi Simental sebanyak 60 buah diperoleh dari BBIB Singosari Malang.

Metode penelitian yang digunakan adalah percobaan di Laboratorium menggunakan Rancangan Acak Lengkap (RAL) Faktorial dengan 6 perlakuan dan masing-masing diulang sebanyak 10 kali. Faktor pertama yaitu suhu thawing dan faktor kedua yaitu lama thawing. Variabel yang diamati antara lain motilitas, viabilitas dan abnormalitas semen beku.

Data yang diperoleh dianalisis menggunakan metode Analisis Varian. Apabila perlakuan memberikan pengaruh maka dilanjutkan dengan uji Beda Nyata Terkecil (BNT).

\section{HASIL DAN PEMBAHASAN}

Tabel 1 menunjukkan hasil evaluasi mikroskopis tentang kualitas spermatozoa semen beku sapi Simental dengan perlakuan suhu $25^{\circ} \mathrm{C}$ dan $37^{\circ} \mathrm{C}$ dan lama thawing 7 detik, 15 detik dan 30 detik serta interaksi kedua faktor tersebut memiliki pengaruh yang sangat nyata $(\mathrm{P}<0,01)$ terhadap tingkat motilitas, viabilitas dan abnormalitas spermatozoa..

Tabel 1. Motilitas, viabilitas, dan abnormalitas hasil thawing

\begin{tabular}{ccccc}
\hline Suhu & $\begin{array}{c}\text { Lama thawing } \\
(\text { detik })^{2}\end{array}$ & $\begin{array}{c}\text { Motilitas } \\
(\%)\end{array}$ & $\begin{array}{c}\text { Viabilitas } \\
(\%)\end{array}$ & $\begin{array}{c}\text { Abnormalitas } \\
(\%)\end{array}$ \\
\hline $37^{\circ} \mathrm{C}$ & 7 & $24,2 \pm 0,79^{\mathrm{c}}$ & $53,476 \pm 0,19^{\mathrm{c}}$ & $5,14 \pm 0,13^{\mathrm{c}}$ \\
& 15 & $40,8 \pm 0,92^{\mathrm{e}}$ & $74,411 \pm 0,14^{\mathrm{e}}$ & $4,88 \pm 0,08^{\mathrm{b}}$ \\
& 30 & $45,5 \pm 0,71^{\mathrm{f}}$ & $75,646 \pm 0,03^{\mathrm{f}}$ & $4,71 \pm 0,1^{\mathrm{a}}$ \\
$25^{\circ} \mathrm{C}$ & 7 & $14,5 \pm 0,71^{\mathrm{a}}$ & $40,371 \pm 0,06^{\mathrm{a}}$ & $5,78 \pm 0,08^{\mathrm{d}}$ \\
& 15 & $20,7 \pm 0,82^{\mathrm{b}}$ & $50,462 \pm 0,04^{\mathrm{b}}$ & $5,38 \pm 0,08^{\mathrm{f}}$ \\
& 30 & $35,5 \pm 0,71^{\mathrm{d}}$ & $69,553 \pm 0,06^{\mathrm{d}}$ & $5,56 \pm 0,05^{\mathrm{e}}$ \\
\hline
\end{tabular}

Keterangan: notasi yang berbeda ${ }^{\text {a-f }}$ pada kolom yang sama menunjukkan perbedaan yang sangat nyata $(P<0,01)$ terhadap motilitas, viabilitas dan abnormalitas semen beku sapi Simental

\section{Persentase motilitas spermatozoa}

Berdasarkan hasil dari evaluasi mikroskopis terhadap perlakuan semen beku menunjukkan bahwa suhu dan lama thawing berpengaruh sangat nyata $(\mathrm{P}<0,01)$ terhadap persentase motilitas spermatozoa. Berdasarkan rataan persentase motilitas spermatozoa terlihat bahwa hasil persentase motilitas terendah rata-rata $14,5 \%$ pada perlakuan dengan suhu $25{ }^{\circ} \mathrm{C}$ dan lama thawing 7 detik, dan hasil tertinggi dengan ratarata $45,5 \%$ pada perlakuan dengan suhu $37{ }^{\circ} \mathrm{C}$ dan lama thawing 30 detik.

Hasil uji BNT 1\% menunjukkan bahwa perlakuan dan kombinasi antara suhu dan lama thawing berpengaruh sangat nyata $(\mathrm{P}<0,01)$ terhadap tingkat motilitas spermatozoa sapi Simental. Persentase motilitas spermatozoa ketika 
pada suhu $37{ }^{\circ} \mathrm{C}$ dengan lama thawing 30 detik sebesar $45,5 \pm 0,707$, namun saat perlakuan pada suhu yang sama, dan lama thawing selama 15 detik mengakibatkan penurunan sebesar $4,7 \%$ dan selama 7 detik terjadi penurunan sebesar 21,3\%. Begitu juga pada saat perlakuan dengan suhu $25^{\circ} \mathrm{C}$. Pada perlakuan dengan suhu $25^{\circ} \mathrm{C}$ dan lama thawing 30 detik masih menunjukkan $35,5 \pm 0,707$, namun terjadi penurunan pada perlakuan 15 detik sebesar $14,8 \%$ dan pada perlakuan 7 detik sebesar $21 \%$.

Standar Nasional Indonesia (SNI) mensyaratkan bahwa standar minimal motilitas untuk IB adalah 40\% (BSN, 2005). Hasil pada perlakuan dengan suhu $37^{\circ} \mathrm{C}$ dan lama thawing 30 detik ini menunjukkan bahwa motilitas spermatozoa memiliki kualitas semen yang sangat baik. Hal ini sesuai dengan pendapat Ismaya (2014) bahwa pengamatan motilitas massa yang dijaga dengan suhu $37{ }^{\circ} \mathrm{C}$ mempunyai kualitas spermatozoa dengan nilai sangat baik $(+++)$. Sedangkan persentase terendah ditemukan pada perlakuan dengan suhu $25{ }^{\circ} \mathrm{C}$ selama 7 detik yang diduga karena proses thawing terlalu cepat dan suhu air standar sehingga spermatozoa lebih banyak tidak bergerak maupun bergerak mundur. Hal ini sesuai dengan pendapat Feradis (2010) bahwa cold shock mengakibatkan pergerakan mundur dan melingkar pada spermatozoa. Apabila spermatozoa tersebut memiliki gerakan berayun atau berhenti bergerak maka dianggap mati.

\section{Persentase viabilitas spermatozoa}

Berdasarkan evaluasi mikroskopis terhadap perlakuan semen beku menunjukkan bahwa suhu dan lama thawing berpengaruh sangat nyata $(\mathrm{P}<0,01)$ terhadap persentase viabilitas spermatozoa semen beku sapi Simental. Persentase viabilitas tertinggi pada per- lakuan thawing dengan suhu $37{ }^{\circ} \mathrm{C}$ selama 30 detik dengan rata-rata $75,646 \%$. Sedangkan viabilitas terendah terdapat pada perlakuan thawing dengan suhu $25^{\circ} \mathrm{C}$ selama 7 detik dengan ratarata 40,371\%. Hasil analisa uji BNT 1\% menunjukkan bahwa setiap perlakuan dan kombinasi antara suhu dan lama thawing berpengaruh sangat nyata $(\mathrm{P}<0,01)$ terhadap tingkat persentase viabilitas spermatozoa. Pada perlakuan $37{ }^{\circ} \mathrm{C}$ yang semula pada lama thawing 30 detik mampu menghasilkan viabilitas rata-rata $75,646 \%$ mengalami penurunan pada lama thawing 15 detik sebesar $1,24 \%$ dan 7 detik sebesar $22,17 \%$. Begitu juga dengan perlakuan pada suhu $25^{\circ} \mathrm{C}$ yang semula dengan lama thawing 30 detik mampu menghasilkan viabilitas rata-rata $69,553 \%$ mengalami penurunan pada lama thawing 30 detik sebesar 19,091\% dan 7 detik sebesar 29,182\%. Penurunan persentase viabilitas ini dimungkinkan bahwa apabila suhu dan lama thawing dibawah optimal maka spermatozoa mengalami tekanan (cold shock) (Arifiantini dan Purwantara, 2010). Hasil penelitian ini masih bisa digunakan dalam kegiatan IB karena seusai dengan pernyataan Hafez (2008) bahwa viabilitas normal semen segar sapi sebesar $60-80 \%$ dan suhu yang optimum untuk daya tahan hidup spermatozoa adalah $37-38^{\circ} \mathrm{C}$.

\section{Persentase abnormalitas spermatozoa}

Berdasarkan hasil dari evaluasi mikroskopis terhadap perlakuan semen beku menunjukkan bahwa suhu dan lama thawing memiliki pengaruh yang sangat nyata $(\mathrm{P}<0,01)$ terhadap persentase abnormalitas spermatozoa. Tingkat persentase abnormalitas tertinggi terletak pada perlakuan suhu $25{ }^{\circ} \mathrm{C}$ dan lama thawing 7 detik dengan rataan $5,78 \%$, sedangkan abnormalitas paling rendah diperoleh pada perlakuan dengan 
suhu $37{ }^{\circ} \mathrm{C}$ dan lama thawing 30 detik dengan rataan 4,71\%. Hasil uji BNT 1\% menunjukkan kombinasi perlakuan antara suhu dan lama thawing memiliki pengaruh paling tinggi pada suhu $25^{\circ} \mathrm{C}$ dengan lama thawing 7 detik.

Hal ini diduga semakin cepat waktu dan suhu perlakuan bisa menyebabkan stres untuk spermatozoa tersebut, sehingga spermatozoa tidak mampu melewati masa kritis selama thawing karena singkatnya waktu dan kurangnya suhu. Hal ini sesuai dengan pendapat Arifiantini dan Purwantara (2010) bahwa pengeringan yang terlalu cepat dan dipanaskan dengan temperatur tinggi dapat mempengaruhi persentase abnormalitas spermatozoa.

Abnormalitas tertinggi dalam penelitian ini menunjukkan rataan $5,78 \pm 0,08$ sehingga masih dapat dipergunakan untuk keperluan inseminasi buatan. Standar Nasional Indonesia (SNI) mensyaratkan bahwa semen sapi memiliki morfologi abnormalitas baik primer maupun sekunder $<20 \%$ (BSN, 2005). Pernyataan serupa juga dinyatakan oleh Balls and Peters (2004) dimana seekor pejantan tidak akan memiliki fertilitas yang tinggi apabila ditemukan spermatozoa abnormalitas sebesar $>17 \%$. Hasil penelitan yang dilakukan oleh Makhzoomi dkk (2007) tentang abnormalitas juga menyebutkan bahwa tingkat abnormalitas primer spermatozoa $<10 \%$ dapat berpengaruh terhadap fertilitas.

\section{KESIMPULAN}

Hasil penelitian menyimpulkan bahwa kualitas spermatozoa semen beku sapi Simental yang optimal dengan suhu thawing $37{ }^{\circ} \mathrm{C}$ dan lama thawing 30 detik mampu menghasilkan nilai rataan tertinggi motilitas sebesar $45,5 \%$ dan viabilitas $75,646 \%$ serta abnormalitas yang cukup rendah yakni $4,71 \%$.

\section{DAFTAR PUSTAKA}

Arifiantini, R. I., dan B. Purwantara. 2010. Motility and viability of Friesian Holstein spermatozoa in three different extender stored at $5{ }^{\circ} \mathrm{C}$. Jurnal of the Indonesian Tropical Animal Agriculture. Vol. 35 No. 4 Desember 2010.

Badan Standardisasi Nasional. 2005. Semen beku sapi. BSN

Ball P. J. H., and Peters A. R. 2004. Reproduction in cattle. 3rd ed. UK: Blackwell Publishing.

Feradis. 2010. Bioteknologi reproduksi pada ternak. Alfabeta. Bandung.

Hafez, E. S. E. 2008. Anatomy of female reproduction. Ed pp. 29-55.

Ismaya. 2014. Bioteknologi inseminasi buatan pada sapi dan kerbau. Gajah MadaUniversity Press. Yogyakarta.

Kartasudjana, R. 2001. Teknik inseminasi buatan pada ternak. Departemen Pendidikan Nasional. Direktorat Pendidikan Menengah Kejuruan Jakarta.

Makhzoomi, A., Lundeheim, N., Haard M., and Rodrigue-Martinez, $\mathrm{H}$. 2007. Sperm morphology and fertility of progreny-tested $\mathrm{Al}$ Swedish dairy bull.J. of Anim. and Vet. Advances 8:975-980.

Yendraliza. 2008. Inseminasi buatan pada ternak. SUSKA press. Pekanbaru.

Yunus, A. 2014. Sukses usaha pembibitan sapi dan kambing. Pustaka Baru Press. Bantul, Yogyakarta. 